\title{
The protective effect of influenza vaccination on the clinical course of coronary disease in patients with acute coronary syndromes treated by primary PCI - a report from FLUCAD study
}

Wpływ szczepienia przeciw grypie na przebieg choroby wieńcowej u pacjentów po pierwotnej angioplastyce wieńcowej - obserwacja z badania FLUCAD

\author{
Andrzej Ciszewski, Zofia T. Bilińska, Cezary Kępka, Mariusz Kruk, Ewa Księżycka-Majczyńska, Witold Rużyłło \\ Institute of Cardiology, Warsaw, Poland
}

Post Kardiol Interw 2010; 6, 1 (19): 6-11

\begin{abstract}
Background and aim: We compared the protective effect of influenza vaccination on the clinical course of coronary artery disease (CAD) in patients (pts) with acute coronary syndrome (ACS) treated by primary angioplasty (PCI), and in stable angina pts.

Methods: Prospective, randomized $1: 1$, double-blind, placebo controlled study. We included 658 optimally treated CAD pts; 477 men, mean age $59.9 \pm 10.3$ years. Median follow-up was 298 (interquartile range 263-317) days.

Results: There were 157 pts ( 83 - active vaccine, 74 - placebo) vaccinated after primary PCI in ACS, and 501 pts (242 - vaccine, 259 - placebo) with stable angina. In stable angina pts there were no significant differences in estimated 12-month cumulative event rates between vaccinated and placebo groups for the: primary endpoint (cardiovascular death), secondary endpoints: major adverse cardiac event (MACE) - (cardiovascular death or myocardial infarction or coronary revascularization) and coronary ischemic event (composite of MACE or hospitalization for angina). In ACS group, in vaccinated pts we observed: (1) a significant reduction in the rate of coronary ischemic event with HR 0.37 (95\% CI 0.14-0.99, p=0.047); (2) a statistical trend for reduction of MACE with HR 0.36 (95\% $\mathrm{Cl} 0.09-1.39 ; \mathrm{p}=0.139$ ); (3) no effect on cardiovascular mortality.

Conclusions: The protective effect of influenza vaccination on CAD clinical course was observed in pts with ACS but not in those with stable angina. Influenza vaccination may be safely performed immediately after ACS and primary PCI.
\end{abstract}

Key words: influenza vaccination, coronary artery disease, primary $\mathrm{PCl}$

\section{Streszczenie}

Wstęp i cel: Pomimo że szczepienie przeciw grypie (SzPG) jest zalecane u osób z chorobą wieńcową (ChW), jego skuteczność w poszczególnych podgrupach pacjentów pozostaje nieznana. W pracy porównano efekt SzPG u pacjentów po ostrych zespołach wieńcowych (OzW) leczonych pierwotną angioplstyką wieńcową $(\mathrm{PCl})$ z efektem u osób ze stabilną chorobą wieńcową (SChW).

Metody: Przeprowadzono prospektywne, kontrolowane placebo badanie kliniczne z randomizacją, metodą podwójnie ślepej próby. Grupę badaną stanowiło 658 pacjentów (w tym 477 mężczyzn) z ChW w wieku 59,9 \pm 10,3 roku. Za pierwotny punkt końcowy badania przyjęto zgon sercowo-naczyniowy w okresie 12 miesięcy. Ustalono dwa równorzędne, złożone punkty końcowe: (1) poważne incydenty sercowe (MACE) (zgon sercowo-naczyniowy lub zawał serca, lub rewaskularyzacja wieńcowa; (2) wieńcowy incydent niedokrwienny (CIE) (MACE bądź hospitalizacja wieńcowa).

Wyniki: Zaszczepiono 157 pacjentów (83 - aktywna szczepionka, 74 - placebo) bezpośrednio po OzW leczonym PCI oraz 501 pacjentów (242 - aktywna szczepionka, 259 - placebo) z SChW. Mediana obserwacji wyniosła 298 (zakres międzykwartylowy 263-317) dni. Wśród chorych z SChW nie obserwowano istotnej różnicy w częstości występowania pierwotnego i złożonych punktów końcowych badania pomiędzy grupą z aktywną szczepionką a grupą placebo. W grupie chorych po OZW, w której pacjenci otrzymali aktywną szczepionkę, w porównaniu z placebo stwierdzono: (1) znamienne zmniejszenie częstości występowania ClE (HR 0,37, $95 \%$ Cl 0,14-0,99, p = 0,047); (2) statystyczny trend do zmniejszenia częstości MACE (HR 0,36, 95\% Cl 0,09-1,39, p = 0,139); (3) brak wpływu na występowanie zgonu sercowo-naczyniowego.

\section{Adres do korespondencji/Corresponding author:}

Andrzej Ciszewski MD, PhD, Instytut Kardiologii, ul. Alpejska 42, 04-628 Warszawa, tel.: +48 660510 763, fax: +48 22812 13 46,

e-mail: aciszewski@ikard.pl

Praca wpłynęła 05.03.2010, przyjęta do druku 12.03.2010.

Clinical trial registration number: NCT 00371098. URL: www.clinicaltrials.gov 
Wnioski: Szczepienie przeciw grypie wpływa korzystnie na przebieg kliniczny choroby wieńcowej u pacjentów po OzW leczonym pierwotną $\mathrm{PCl}$, natomiast nie stwierdzono takiego efektu u chorych z SChW.

Słowa kluczowe: szczepienie przeciw grypie, choroba wieńcowa, pierwotna angioplastyka

\section{Background}

Inflammation and infection play an important role in the progression of atherosclerosis and destabilization of angina [1-5]. Several studies have indicated that influenza vaccination reduces cardiovascular mortality, the incidence of myocardial infarction (MI) and stroke [6-9]. In our previous report of the randomized, double-blind, placebo controlled FLUCAD study, we found that influenza vaccination reduced the incidence of coronary ischemic events in patients with confirmed coronary artery disease (CAD) [10].

As our study group was not clinically homogenous, we decided to investigate the potential difference in the protective effect of influenza vaccination between patients with stable angina and those with acute coronary syndrome (ACS) vaccinated after primary $\mathrm{PCl}$.

\section{Material and methods \\ Patients and protocol}

FLUCAD study is a prospective, randomized, double blind, single center, placebo controlled study performed to evaluate the effect of influenza vaccination on the incidence of coronary events in patients with CAD. The details of the study protocol were published previously [10]. In brief, 658 patients (477 men) aged $59.9 \pm 10.3$ years randomly received intramuscular inactivated sub-unit influenza vaccine (Influvac, SolvayPharma) for 2004/2005 season, or placebo containing all vaccine compounds except viral antigens. The randomization was 1:1 (influenza or placebo vaccine).

Patients were eligible if they were aged $30-80$ years, and had CAD confirmed by angiography with at least 50\% stenosis of at least one large epicardial coronary artery. We excluded patients with congestive heart failure NYHA III/IV, planned cardiovascular surgery within 6 months, evolving renal failure, contraindication to vaccination, or any factor impeding follow-up. The ACS group consisted of patients with: ST elevation ACS (STEMI), non-ST elevation ACS (NSTEMI) and troponin negative ACS. All ACS patients were treated by primary $\mathrm{PCl}$, and were vaccinated within a week after coronary intervention, before discharge from the hospital. Outpatients were vaccinated during office visits to cardiologists.

Patients were recruited and vaccinated from October 2004 to February 2005. All cardiovascular events and study endpoints were confirmed by source documents. The follow-up was censored for all participants on October $31^{\text {st }}$, 2005.

The primary endpoint was 12-month cardiovascular death. There were two secondary endpoints: major adverse cardiac event (MACE), which was the composite of: cardiovascular death, acute myocardial infarction (MI), or coronary revascularization and coronary ischemic event, defined as a combination of MACE or hospitalization for myocardial ischemia, both assessed at 12-month.

STEMI and NSTEMI were diagnosed on the criteria described previously, basing on AHA guidelines [10].

\section{Statistical analysis}

All analyses were done on a intention-to-treat basis. Results are presented as median, (25th and $75^{\text {th }}$ percentile), for continuous variables, and as percentages for categorical data. Groups were compared (all tests two-sided) by unpaired t-test or one way analysis of variance for normally distributed variables or Mann-Whitney-Wilcoxon test, where data were not normally distributed. Frequencies were compared using chi-square or Fisher's exact test, where appropriate. Survival curves were assessed by Kaplan-Meier method and compared using a log-rank test. Hazard ratios (HR) and 95\% confidence intervals were calculated by the Cox proportional hazards model. Estimated 12-month cumulative rate of the study endpoints in vaccinated versus placebo patients was presented as percentages based on Kaplan-Meier method. In measuring the time to an event for cases in which a patient had multiple end-points, the first event was taken into account.

Multivariable Cox regression model included major causal risk factors for CAD: age, sex, smoking, arterial hypertension, elevated LDL-cholesterol ( $\geq 3.12 \mathrm{mmol} / \mathrm{l})$, low HDL-cholesterol $(\leq 0.9 \mathrm{mmol} / \mathrm{l})$, and diabetes along with influenza vaccination, and recent ACS.

Data were analyzed using the SAS package, ver. 8.2. The $p$ values $<0.05$ were considered significant.

The authors had full access to the data and take responsibility for its integrity. All authors have read and agreed to the manuscript as written.

\section{Results}

\section{Study population}

We included and vaccinated 658 Caucasian patients (477 men), mean age $59.9 \pm 10.3$ years. Three hundred twenty five patients received influenza vaccine and 333 patients received placebo. Median follow-up time was 298 (263-317) days, range 4-370 (measured to the first event or to the end of the observation period). No patient was lost to the follow-up. Detailed characteristics of study groups are listed in table 1.

Among 157 ACS patients, 83 received active vaccine and 74 placebo. In ACS group there were 81 STEMI, 43 NSTEMI and 33 Troponin negative ACS patients. Of the 501 stable angina patients, 242 received active vaccine and 
259 placebo. Stable group consisted of 370 outpatients with angiographically confirmed CAD and 131 patients hospitalized for elective PCI.

\section{Impact of vaccination on clinical outcomes in ACS patients}

In ACS group (tab. 2, fig. $1 \mathrm{~A}, \mathrm{C}, \mathrm{E}$ ) the primary endpoint - the estimated 12-month cumulative cardiovascular death rate was $1.2 \%$ in vaccinated and $0 \%$ in placebo patients $(p=0.623)$.

The MACE tended to occur less frequently in the vaccine group in comparison to placebo, with a statistical trend 4.66 vs. $9.63 \%$ respectively, HR $0.36(95 \% \mathrm{Cl} 0.09$ $1.39, \mathrm{p}=0.139$ ).

For coronary ischemic event the estimated 12-month cumulative event rate was significantly lower in the vaccine group (11.63\%) than in the placebo group (19.29\%), with a HR 0.37 (95\% Cl 0.14-0.99, p = 0.047) (tab. 2).

\section{Impact of vaccination on clinical outcomes in stable angina patients}

In the stable angina group (tab. 3, fig. 1 B, D, F) we found no statistically significant effect of the influenza vaccination either on cardiovascular death, or any of the secondary endpoints (MACE and coronary ischemic event).

\section{Discussion}

Our results show in a prospective, randomized, double blind, placebo-controlled study the difference of the protective effect of influenza vaccination on the clinical course of CAD between patients with ACS treated by

Table 1. Baseline characteristics of the study population $(n=658)$

Tabela 1. Charakterystyka badanej grupy $(n=658)$

\begin{tabular}{|c|c|c|c|}
\hline Variable & $\begin{array}{c}\text { ACS-primary PCl } \\
n=157\end{array}$ & $\begin{array}{l}\text { Stable angina } \\
\quad n=501\end{array}$ & $\mathrm{p}$ \\
\hline \multicolumn{4}{|l|}{ Demographic/epidemiological factors } \\
\hline Age [years] & $58.5(50.9-69.1)$ & $58.3(51.0-67.3)$ & 0.82 \\
\hline Male gender, n (\%) & $106(67.5)$ & $371(74.5)$ & 0.12 \\
\hline $\mathrm{BMI}\left[\mathrm{kg} / \mathrm{m}^{2}\right]$ & $27.2(24.9-30.8)$ & $27.9(25.5-30.4)$ & 0.31 \\
\hline Height $[\mathrm{cm}]$ & $170(162-175)$ & $170(165-176)$ & 0.10 \\
\hline Influenza vaccination within previous year, n (\%) & $8(5.1)$ & $31(6.2)$ & 0.70 \\
\hline \multicolumn{4}{|l|}{ Cardiovascular/risk factors } \\
\hline Hypertension, n (\%) & $98(62.8)$ & $338(67.7)$ & 0.28 \\
\hline Diabetes, n (\%) & $34(21.7)$ & $99(19.8)$ & 0.65 \\
\hline Smoking, n (\%) & $55(35.0)$ & $66(13.2)$ & 0.003 \\
\hline $\operatorname{LVEF}[\%]$ & $50(52-58)$ & $54(45-60)$ & 0.008 \\
\hline 2 or 3 vessel disease, $n(\%)$ & $92(59.4)$ & $352(71.8)$ & 0.003 \\
\hline Total cholesterol [mmol/l] & $5.36(4.47-6.06)$ & $4.44(3.9-5.0)$ & 0.0001 \\
\hline LDL-cholesterol [mmol/I] & $3.65(3.05-4.46)$ & $2.79(2.15-3.25)$ & 0.0001 \\
\hline HDL-cholesterol [mmol/l] & $1.28(105-1.44)$ & $1.24(1.08-1.50)$ & 0.94 \\
\hline Triglycerides $[\mathrm{mmol} / \mathrm{l}]$ & $1.60(1.17-2.19)$ & $1.35(1.05-1.84)$ & 0.003 \\
\hline Creatinine $[\mathrm{mmol} / \mathrm{l}]$ & $76(62-85)$ & $90(77-106)$ & 0.0001 \\
\hline $\mathrm{hs}-\mathrm{CRP}[\mathrm{mg} / \mathrm{dl}]$ & $0.60(0.26-1.20)$ & $0.21(0.10-0.56)$ & 0.0001 \\
\hline \multicolumn{4}{|l|}{ Clinical history } \\
\hline Myocardial infarction, n (\%) & $47(29.9)$ & $395(78.8)$ & 0.0001 \\
\hline $\mathrm{PCl}, \mathrm{n}(\%)$ & $28(17.8)$ & $330(65.8)$ & 0.0001 \\
\hline Coronary bypass, n (\%) & $15(9.5)$ & $69(13.8)$ & 0.22 \\
\hline Atrial fibrillation, n (\%) & $4(2.5)$ & $11(2.2)$ & 0.76 \\
\hline Stroke, n (\%) & $8(5.1)$ & $22(4.4)$ & 0.67 \\
\hline Heart failure, n (\%) & $17(10.9)$ & $78(15.7)$ & 0.15 \\
\hline \multicolumn{4}{|l|}{ Actual treatment } \\
\hline Aspirin, n (\%) & $157(100)$ & $485(96.8)$ & 0.016 \\
\hline Thienopiridines, n (\%) & $157(100)$ & $178(35.5)$ & 0.0001 \\
\hline Statins, n (\%) & $154(98.1)$ & $494(98.6)$ & 0.71 \\
\hline Beta-blockers, n (\%) & $149(94.9)$ & $471(94.0)$ & 0.85 \\
\hline ACE inhibitors, n (\%) & $144(91.7)$ & $465(92.8)$ & 0.61 \\
\hline Diuretics, n (\%) & $31(19.7)$ & $121(24.1)$ & 0.28 \\
\hline Oral hypoglycemic, n (\%) & $26(16.6)$ & $79(15.8)$ & 0.80 \\
\hline Insulin, n (\%) & $7(4.5)$ & $27(5.4)$ & 0.84 \\
\hline
\end{tabular}

$\mathrm{BMI}$ - body mass index, LVEF - left ventricular ejection fraction, $\mathrm{PCI}$ - percutaneous coronary intervention Results are presented as median (range) for continuous data, and as percentages for categorical data $B M I$ - wskaźnik masy ciała, LVEF - frakcja wyrzutowa lewej komory, PCl-przezskórna interwencja wieńcowa 
cardiovascular death

A

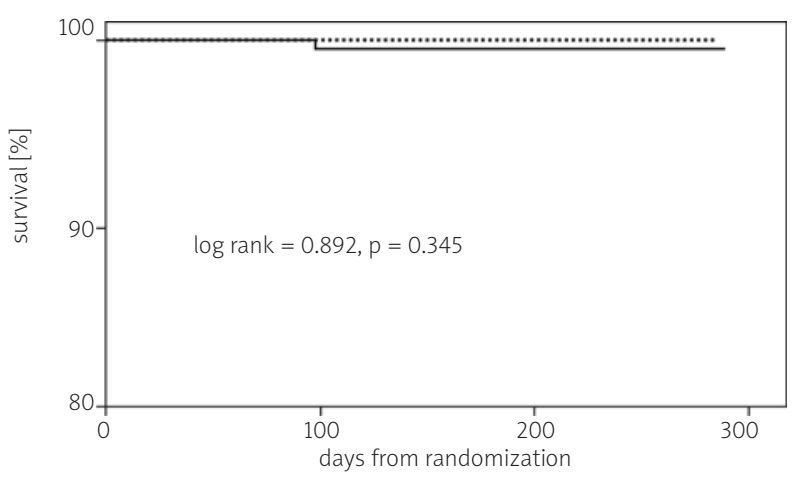

\begin{tabular}{l|cccccccccc} 
days & 0 & 30 & 60 & 100 & 150 & 200 & 250 & 300 & &
\end{tabular} …...... placebo

MACE

C

patients with acute coronary syndrome

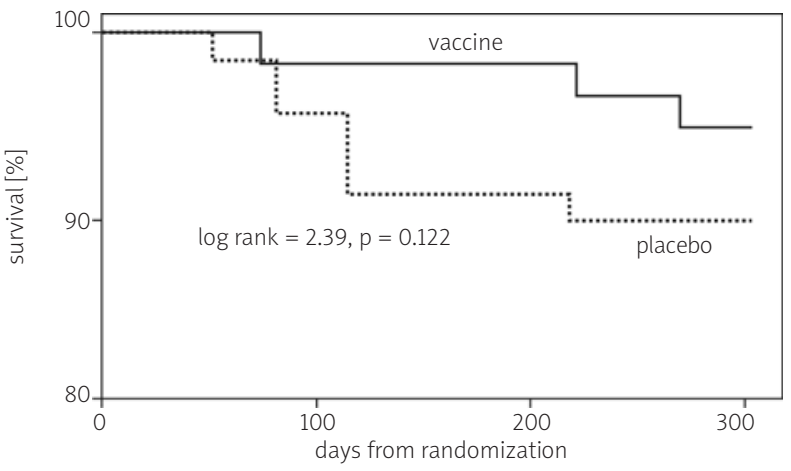

$\mathrm{D}$
B

patients with stable angina

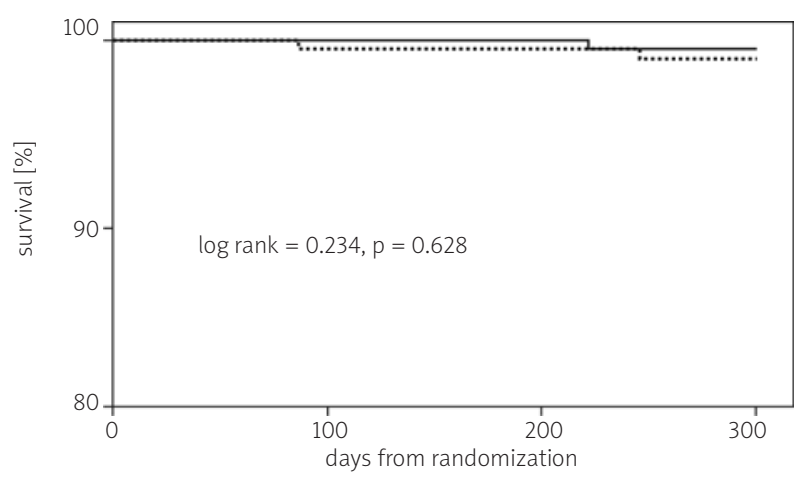
\begin{tabular}{l|lllllllll}
\hline vaccine & 0 & 0 & 0 & 0 & 0 & 1 & 0 & 0
\end{tabular} placebo $\begin{array}{lllllllll}0 & 0 & 1 & 0 & 0 & 0 & 1 & 0\end{array}$

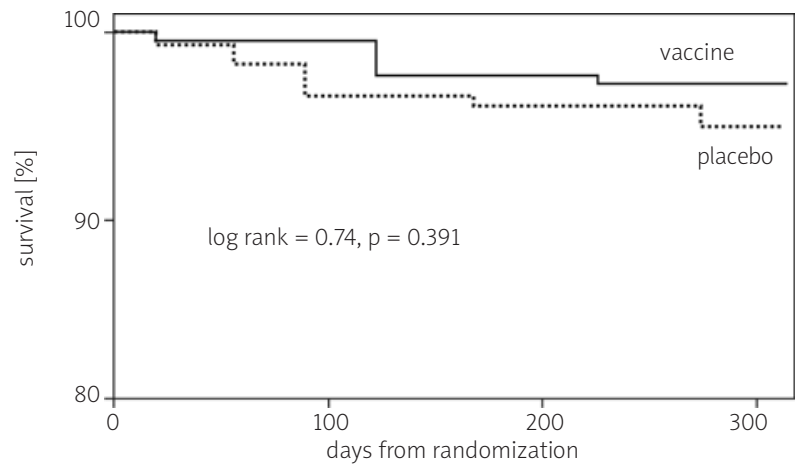

coronary ischemic event

E

E patients with acute coronary syndrome

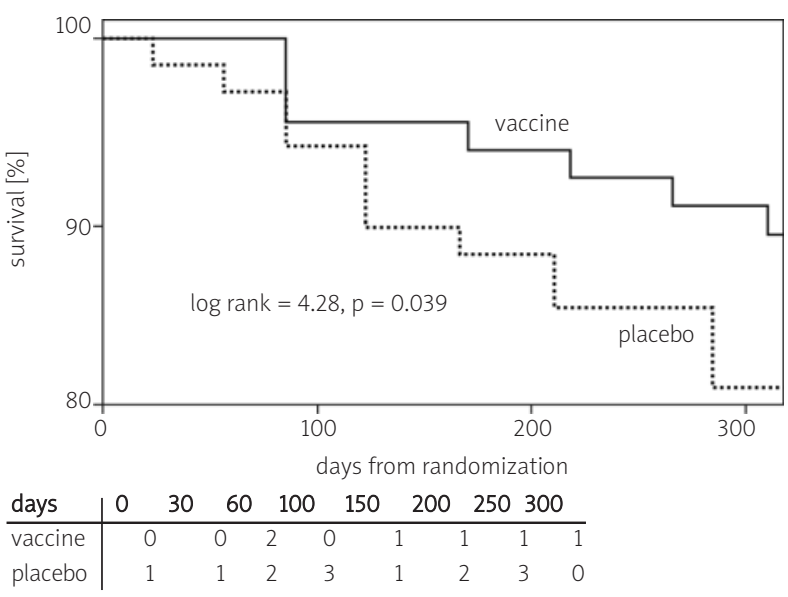

$\mathrm{F}$

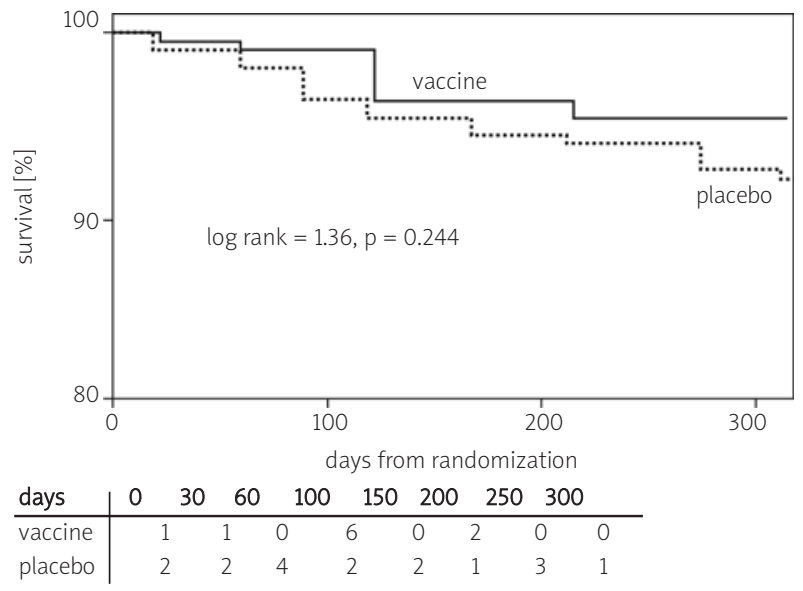

Fig. 1. Kaplan-Meier curves of event free survival for 3 study endpoints: cardiovascular death, MACE (major adverse cardiac events) and coronary ischemic event. The comparison of the effect of influenza vaccination in patients with acute coronary syndrome and stable angina

Ryc. 1. Krzywe Kaplana-Meiera występowania 3 punktów końcowych badania: zgonu sercowo-naczyniowego, MACE (poważnych incydentów sercowych: zgon sercowo-naczyniowy lub zawał serca, lub rewaskularyzacja wieńcowa) i wieńcowych incydentów niedokrwiennych (MACE bądź hospitalizacja wieńcowa). Porównanie wpływu szczepienia przeciw grypie u chorych z ostrym zespotem wieńcowym i stabilną chorobą wieńcowa 
Table 2. The study endpoints in patients with ACS ( $\mathrm{n}=157)$

Tabela 2. Występowanie punktów końcowych badania u chorych z ACS ( $n=157)$

\begin{tabular}{|c|c|c|c|c|c|}
\hline \multicolumn{2}{|c|}{$\begin{array}{l}\text { Vaccine } \\
(n=83)\end{array}$} & \multicolumn{2}{|c|}{$\begin{array}{l}\text { Placebo } \\
(n=74)\end{array}$} & \multirow[t]{2}{*}{$\begin{array}{l}\text { Hazard ratio } \\
(95 \% \mathrm{Cl})\end{array}$} & \multirow[t]{2}{*}{$\mathrm{p}$} \\
\hline $\begin{array}{l}\text { Number } \\
\text { of events }\end{array}$ & $\begin{array}{l}\text { Estimated } 12 \text {-month } \\
\text { cumulative event rate }\end{array}$ & $\begin{array}{l}\text { Number } \\
\text { of events }\end{array}$ & $\begin{array}{l}\text { Estimated } 12 \text {-month } \\
\text { cumulative event rate }\end{array}$ & & \\
\hline \multicolumn{6}{|c|}{ Primary endpoint - cardiovascular death } \\
\hline 1 & $1.2 \%$ & 0 & $0 \%$ & $57.1\left(0.01-584 \times 10^{6}\right)$ & 0.623 \\
\hline \multicolumn{6}{|l|}{ Secondary endpoints } \\
\hline \multicolumn{6}{|c|}{ MACE: cardiovascular death, MI, or coronary revascularization } \\
\hline 3 & $4.66 \%$ & 7 & $9.63 \%$ & $0.36(0.09-1.39)$ & 0.139 \\
\hline \multicolumn{6}{|c|}{ myocardial infarction (STEMI/NSTEMI) } \\
\hline 2 & $3.49 \%$ & 7 & $9.63 \%$ & $0.24(0.05-1.15)$ & 0.074 \\
\hline \multicolumn{6}{|c|}{ coronary revascularization (PCI/CABG) } \\
\hline 0 & & 0 & - & - & - \\
\hline \multicolumn{6}{|c|}{ Coronary ischemic event: MACE or hospitalization for myocardial ischemia } \\
\hline 6 & $11.63 \%$ & 13 & $19.29 \%$ & $0.37(0.14-0.99)$ & 0.047 \\
\hline \multicolumn{6}{|c|}{ hospitalization for myocardial ischemia } \\
\hline 3 & $7.32 \%$ & 6 & $10.69 \%$ & $0.39(0.10-1.57)$ & 0.185 \\
\hline
\end{tabular}

MACE - major adverse cardiac event, STEMI - ST-elevation myocardial infarction, NSTEMI - non-ST-elevation myocardial infarction, PCI - percutaneous coronary intervention, CABG - coronary artery bypass graft

MACE - poważne zdarzenie sercowe, STEMI - zawat serca z uniesieniem odcinka ST, NSTEMI - zawat serca bez uniesienia odcinka ST, PCI - przezskórna interwencja wieńcowa, CABG - pomostowanie aortalno-wieńcowe

Table 3. The study endpoints in patients with stable angina $(n=501)$

Tabela 3. Występowanie punktów końcowych badania u osób ze stabilną chorobą wieńcową $(n=501)$

\begin{tabular}{|c|c|c|c|c|c|}
\hline \multicolumn{2}{|c|}{$\begin{array}{l}\text { Vaccine } \\
(n=242)\end{array}$} & \multicolumn{2}{|c|}{$\begin{array}{l}\text { Placebo } \\
(n=259)\end{array}$} & \multirow[t]{2}{*}{$\begin{array}{l}\text { Hazard ratio } \\
(95 \% \mathrm{Cl})\end{array}$} & \multirow[t]{2}{*}{$\mathrm{p}$} \\
\hline $\begin{array}{l}\text { Number } \\
\text { of events }\end{array}$ & $\begin{array}{l}\text { Estimated } 12 \text {-month } \\
\text { cumulative event rate }\end{array}$ & $\begin{array}{l}\text { Number } \\
\text { of events }\end{array}$ & $\begin{array}{l}\text { Estimated } 12 \text {-month } \\
\text { cumulative event rate }\end{array}$ & & \\
\hline \multicolumn{6}{|c|}{ Primary endpoint - cardiovascular death } \\
\hline 1 & $0.43 \%$ & 2 & $0.95 \%$ & $0.55(0.05-6.03)$ & 0.622 \\
\hline \multicolumn{6}{|l|}{ Secondary endpoints } \\
\hline \multicolumn{6}{|c|}{ MACE: cardiovascular death, MI, or coronary revascularization } \\
\hline 6 & $2.51 \%$ & 10 & $4.71 \%$ & $0.65(0.23-1.77)$ & 0.395 \\
\hline \multicolumn{6}{|c|}{ myocardial infarction (STEMI/NSTEMI) } \\
\hline 4 & $1.67 \%$ & 2 & $1.33 \%$ & $2.14(0.39-11.66)$ & 0.381 \\
\hline \multicolumn{6}{|c|}{ coronary revascularization (PCI/CABG) } \\
\hline 1 & $0.43 \%$ & 6 & $2.51 \%$ & $0.18(0.02-1.48)$ & 0.11 \\
\hline \multicolumn{6}{|c|}{ Coronary ischemic event: MACE or hospitalization for myocardial ischemia } \\
\hline 10 & $4.15 \%$ & 17 & $7.41 \%$ & $0.63(0.29-1.38)$ & 0.249 \\
\hline \multicolumn{6}{|c|}{ hospitalization for myocardial ischemia } \\
\hline 4 & $1.68 \%$ & 7 & $2.83 \%$ & $0.61(0.18-2.09)$ & 0.434 \\
\hline
\end{tabular}

Abbreviations: see table 2

Objaśnienia: zobacz tabela 2.

primary $\mathrm{PCl}$ and those with stable angina. The beneficial effect of vaccination is evident in patients vaccinated in the clinically unstable period of angina, with recent ACS (tab. 2, fig. 1 E). Despite a much bigger cohort of patients, we did not prove such an effect with statistical significance in patients with stable angina (tab. 3, fig. 1 B, D, F).
Another important finding is that the protective effect of influenza vaccination was present through the whole followup and it extended beyond the period of viral circulation (fig. $1 \mathrm{E}$ ). The study also confirms previous sparse reports that influenza vaccination, early after emergency $\mathrm{PCl}$, is safe, and carries no increased risk of cardiovascular events $[9,11]$. 
Despite the recommendation of influenza vaccination in $C A D$ by the European Society of Cardiology some aspects concerning the nature of the effect still remain unclear [12].

The effect of influenza vaccination might be different in relation to the clinical profile and treatment of CAD patients, and it may affect the results of sparse studies. Gurfinkel et al. found in FLUVACS study a significant, 75\% reduction in mortality in a group of 301 CAD patients due to influenza vaccination, but his group was treated very conservatively, developed a large number of cardiac events (5\% mortality rate in 6 months), and the impact of influenza vaccination on: mortality, reinfarction and composite end point was significant [9]. Madjid et al. postulated that influenza vaccination may have a plaque stabilizing effect and may be more beneficial for the subjects who lack access to efficient medical care. Our results confirm this hypothesis. Our ACS patients were vaccinated during the first days after primary coronary interventions, in the phase of unstable CAD and aggravated inflammation. Their hs-CRP level was significantly higher than in the stable angina group (median 0.60 vs. $0.21 \mathrm{mg} / \mathrm{dl}, \mathrm{p}=0.0001$ ). In contrast, the stable group represented optimally treated stable patients, with over $90 \%$ use of beta-blockers, antiplatelets, statins and ACE-inhibitors. In our opinion, it might be very difficult to prove the beneficial effect of influenza vaccination on the already stable angina patients receiving optimal treatment.

The mechanism of the protective effect of influenza vaccination in CAD is not clear. Some authors think that as influenza and all severe acute infections trigger a plaque destabilization $[4,6,11]$.

Other investigators believe in a special, specific relation between influenza and atherosclerosis. They suggest that autoimmune cross-reactivity between influenza antigens and plaque antigens may be responsible for the progression of atherosclerosis and influenza cardiovascular complications [13]. Our observations that the protective effect of influenza vaccination was not restricted to the period of viral circulation suggest that influenza vaccination may influence an immuno-inflammatory mechanism of atherosclerosis.

In conclusion, influenza vaccination reduces the rate of coronary ischemic events and may be safely performed in patients early after ACS and primary PCI. In contrast, in optimally treated, stable angina patients, further stabilization of the CAD course by influenza vaccination, is not evident. The beneficial effect of influenza vaccination in ACS patients was present through the whole follow-up, and was not restricted to the period of viral circulation. A further study is still needed to evaluate life saving and Ml-protecting properties of influenza vaccination, and to clarify the mechanism of its protective effect on the clinical course of coronary disease.

\section{Study limitations}

Our group represented only selected patients who received optimal medical treatment and uncomplicated invasive procedures. The number of cardiac events was lower than expected, and the sample size may be considered too small to evaluate the effect of influenza vaccination on mortality and MACE. Another limitation was that the effect of flu vaccination on restenosis is unknown. Restenosis might be the cause of cardiac events in post $\mathrm{PCl}$ patients, but routine angiography was not performed in this study.

\section{Disclosures and aknowlegments}

The study was financed by the Grant of Polish Ministry of Education and Science No. 2 P05B 01627. Solvay Pharmaceuticals B.V. provided influenza vaccine and placebo vaccine free of charge.

\section{References}

1. Ross R, Glomset JA. The pathogenesis of atherosclerosis (first of two parts). N Eng J Med 1976; 295: 369-377.

2. Kol A, Libby P. Molecular mediators of arterial inflammation: role of microbal products? Am Heart J 1999; 138: S450-S452.

3. Pesonen E, Siitonen O. Acute myocardial infarction precipitated by infectious disease. Am Heart J 1981; 101: 512-513.

4. Spodick DH, Flessas AP, Johnson MM. Association of acute respiratory symptoms with onset of acute myocardial infarction: prospective investigation of 150 consecutive patients and matched control patients. Am J Cardiol 1984; 53: 481-482.

5. Madjid M, Miller CC, Zarubaev VV, et al. Influenza epidemics and acute respiratory disease activity are associated with a surge in autopsy-confirmed coronary heart disease: results from 8 years of autopsies in 34892 subjects. Eur Heart J 2007; 28: 1205-1210.

6. Naghavi M, Barlas Z, Siadaty S, et al. Association of influenza vaccination and reduced risk of recurrent myocardial infarction. Circulation 2000; 102: 3039-3045.

7. Lavallee P, Perchaud V, Gautier-Bertrand M, et al. Association between influenza vaccination and reduced risk of brain infarction. Stroke 2002; 33: 513-518. Erratum in: Stroke 2002; 33: 1171.

8. Siscovick DS, Raghunathan TE, Lin D, et al. Influenza vaccination and the risk of primary cardiac arrest. Am J Epidemiol 2000; 152: 674-677.

9. Gurfinkel EP, de la Fuente RL, Mendiz O, et al. Influenza vaccine pilot study in acute coronary syndromes and planned percutaneous coronary interventions: the FLU Vaccination Acute Coronary Syndromes (FLUVACS) Study. Circulation 2002; 105: 2143-2147.

10. Ciszewski A, Bilinska ZT, Brydak LB, et al. Influenza vaccination in acute prevention from coronary ischemic events in coronary artery disease: FLUCAD study. Eur Heart J 2008; 29: 1350-1358.

11. Smeeth L, Thomas SL, Hall AJ, et al. Risk of myocardial infarction and stroke after acute infection or vaccination. N Eng J Med 2004; 351: 2611-2618.

12. Van de Werf F, Bax J, Betriu A, et al. ESC Guidelines. Management of acute myocardial infarction in patients presenting with persistent ST-segment elevation. The Task Force on the management of STsegment elevation acute myocardial infarction of the European Society of Cardiology. Eur Heart J 2008; 29: 2909-2945.

13. Gurevich VS. Influenza, autoimmunity and atherosclerosis. Autoimmun Rev 2005; 4: 101-105. 